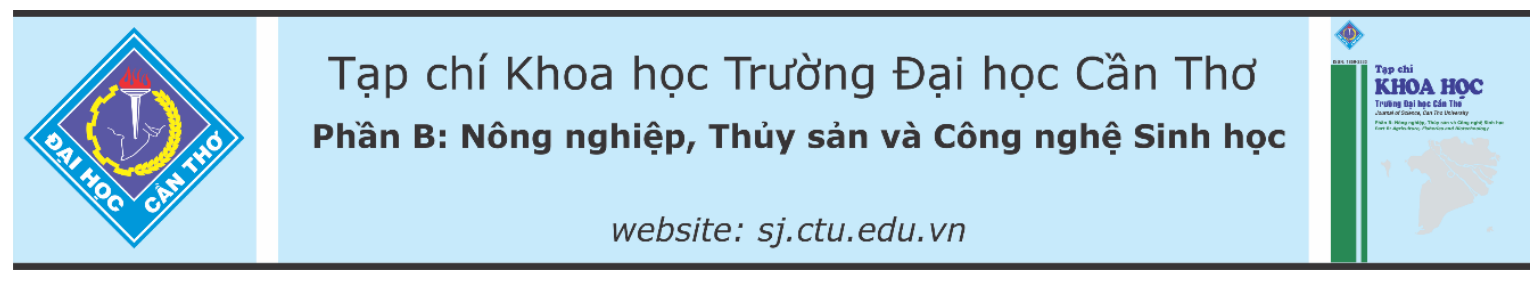

DOI:10.22144/ctu.jvn.2021.103

\title{
HÀM LƯợNG DINH DỮ̃NG MÔI TRƯờNG NƯỚC TỤ NHIÊN KHU VỰC NUÔI CÁ TRA TỈNH AN GIANG
}

\author{
Trần Trung Giang*, Âu Văn Hóa, Trương Quốc Phú, Huỳnh Trường Giang và Vũ Ngọc Út \\ Khoa Thủy sản, Truờng Đại học Cần Tho \\ *Người chịu trách nhiệm về bài viết: Trần Trung Giang (email: trunggiang@ctu.edu.vn)
}

\section{Thông tin chung:}

Ngày nhận bài: 22/01/2021

Ngày nhận bài sủa: 30/04/2021

Ngày duyệt đăng: 25/06/2021

\section{Title:}

Nutrient contents of the natural water environment in striped catfish culture area, An Giang province

\section{Tù khóa:}

An Giang, cá tra, chất lượng nuớc, hàm luợng dinh duỡng

\section{Keywords:}

An Giang, nutrient contents, striped catfish, water quality

\begin{abstract}
The study is aimed to assess the nutrient contents of the natural water environment in striped catfish farming areas, An Giang province. Findings of the study would provide warnings and measures for appropriate water quality management toward the sustainabledevelopment of striped catfish farming and protection of water resources in the area. Samples were collected at 3 sites in the Hau river and 3 sites in water supply canals in the intensive striped catfish farming areas. The samples were collected 4 times a year including March, June, September, and December, 2019. The results showed that nutrient contents at the water supply canals were higher than those on the Hau river. During the dry season, the nutrient contents tended to be higher than in the rainy season, especially in water supply canals. The water quality of the natural water surrounding the intensive striped catfish farming areas was directly affected by fish ponds. Phosphate, total nitrogen and total phosphorus concentrations were high at the sites sampling. It is, therefore, necessary to monitor and apply appropriate treatments when using water for different purposes.
\end{abstract}

\section{TÓM TẮT}

Nghiên cứu nhằm đánh giá các hàm luợng dinh duõng trong môi trường nước tự nhiên tại các khu vự nuôi cá tra tại tỉnh An Giang. Kết quả nghiên cứu sẽ đưa ra những nhận định, cảnh báo để có biện pháp quản lý, xử lý phù hợp về chất lương nước để hướng đến phát triển nghề nuôi cá tra bền vũng của vùng và bảo vệ nguồn tài nguyên nước trong khu vưcc. Mẫu nuớc tầng mặt và mẫu bùn đáy đánh giá đuoợc thu tại 3 điểm ở sông Hậu và 3 điểm các kênh cấp tại các khu vự nuôi cá tra thâm canh của tỉnh. Thời gian thu mẫu được thực hiện 4 đợt trong năm. Kết quả cho thấy hàm luợng dinh duõong tại các điểm thu ở Kênh cấp nộ đồng có giá trị cao hơn so với các điểm thu ở sông Hậu. Vào các đợt mùa khô, hàm luợng dinh duỡng có xu huớng cao hơn so với mùa mua, đặc biệt là các điểm thu ở kênh cáp nội đồng. Chất lượng nước tại các thủy vục tụ nhiên xung quanh khu vục nuôi cá tra thâm canh chịu tác động trực tiếp tù hoạt động nuôi, trao đổi nguồn nước phục vu nuôi cá. Các hàm lương phosphate, tổng nito (TN) và tổng phốtpho (TP) trong nước có giá trị cao tại các điểm thu mẫu, cần có các biện pháp theo dõi, xủ lý chặt chẽ các hàm lượng dinh duỡng trong nước khi sủ dụng nguồn nước với tùng loại muc đich khác nhau.

\section{1. ĐẶT VẤN ĐỀ}

Biến đổi khí hậu đã và đang ảnh hưởng trực tiếp, tác động rất lớn đến ngành nông nghiệp. Sự gia tăng nhiệt độ và tỷ lệ hạn hán, lũ lụt ngày càng tăng ảnh hưởng xấu đến an ninh lương thực (Patz, 2005). Dưới tác động của biến đổi khí hậu, điều kiện khí hậu ở An Giang có những dấu hiệu thay đổi nghiêm 
trọng như hạn hán kéo dài, lũ lụt nhanh, liên tục và kèm theo đó là sạt lở đất. Theo tính toán dựa trên kịch bản biến đổi khí hậu tỉnh An Giang đến năm 2020, tầm nhìn đến năm 2030, tình hình biến đổi khí hậu diễn biến ngày càng phức tạp do thiếu nước trầm trọng vì mùa khô kéo dài, bão lũ bất thường với cường độ lớn. Về khía cạnh thủy văn, tỉnh An Giang nằm ở vị trí đầu nguồn, chịu ngập sâu, là nơi lắng đọng phù sa và các chất dinh dưỡng của cả 2 nhánh sông lớn là sông Tiền và sông Hậu, nhiều nhất là sông Hậu. Đất đai màu mỡ, nước ngọt quanh năm, thuận lợi cho phát triển nông nghiệp và thủy sản nước ngọt thông qua cống, kênh và hệ thống đê điều (Le Anh Tuan et al., 2015). Tuy nhiên, chất lượng nước tầng mặt khu vực có xu hướng kém do hàm lượng chất dinh dưỡng cao trong các kênh cấp. Nguyên nhân là do việc xả thải của các hoạt động nông nghiệp chưa qua xử lý (Minh et al., 2019). Trong đó, sự phát triển đột phá của nghề nuôi cá tra thâm canh đã ảnh hưởng rất lớn đến vấn đề môi trường do chất thải từ ngành nghề này mang lại từ các mô hình nuôi lồng, bè đến hệ thống ao thâm canh. Theo Sở Nông nghiệp và Phát triển nông thôn tỉnh An Giang (2019), toàn tỉnh hiện có 11 cơ sở sản xuất cá tra bột. Tổng đàn cá tra bố mẹ hiện tại khoảng 44.800 con, đàn cá bố mẹ hậu bị 18.000 , khả năng cung ứng được khoảng 6,8-10 tỷ bột/năm, cung cấp cho nhu cầu ương cá tra giống của các hộ nuôi trong tỉnh và các tỉnh Đồng bằng sông Cửu Long. Diện tích cá tra đang nuôi của tỉnh đạt 1.119 ha; diện tích thu hoạch cá tra 853 ha. Sản lượng cá tra thu hoạch 273.939 tấn, bằng $120 \%$ so với cùng kỳ năm 2018. Từ đầu năm 2021, diện tích cá tra thu hoạch trên địa bàn tỉnh đạt 182 ha, sản lượng 54.500 tấn, tăng $2,25 \%$ về diện tích và $3,07 \%$ về sản lượng so cùng kỳ 2020. Số lượng con giống cá tra sản xuất khoảng 280 triệu con, tăng 2 triệu con. Ước tính tổng diện tích nuôi cá tra đạt 1.390 ha, tương đương năm 2020. Về sản lượng đạt 454.000 tấn, tăng 25.000 tấn so năm 2020; sản lượng giống 3,3 tỷ con, tăng 200 triệu con (Sở Nông nghiệp và Phát triển nông thôn tỉnh An Giang, 2021). Theo kết quả điều tra 30 trang trại nuôi cá tra thâm canh ở các tỉnh nuôi cá tập trung như Tiền Giang, Cần Thơ, Bến Tre, An Giang, Đồng Tháp và Vĩnh Long, năng suất trung bình 422 tấn/ha/vụ với thời gian nuôi trung bình 293 ngày/chu kỳ, trọng lượng trung bình thu hoạch $952 \mathrm{~g} / \mathrm{con}$. Trung bình sản xuất $1 \mathrm{~kg}$ cá cần lượng nước $7,4 \mathrm{~m}^{3}$ và sinh ra 19,7 L bùn. Ước tính cân bằng dinh dưỡng của ao đầu vào với dạng vật chất rắn $(\mathrm{DM})$ chiếm $54,7 \%$ từ thức ăn và nước sông chiếm $44,9 \%$. Chất thải đạm nitrogen ước tính đầu vào nước sông $26 \%$ và thức ăn $73,2 \%$. Tỷ lệ phosphorus chiếm cao nhất từ nguồn thức ăn $10,2 \%$ và từ nguồn nước vào $3,4 \%$.
Cá tra thương phẩm hấp thụ nitrogen $33,6 \%$, thải ra môi trường nước $38,5 \%$, bùn chiếm $1,17 \%$ và vi sinh vật hấp thụ khoảng $26,7 \%$. Phosphorus chiếm $30,9 \%$ trong cá, nước thải $30,5 \%$, trong bùn $1,85 \%$ và hấp thụ phần lớn trong vi sinh vật $36,7 \%$ (Nguyễn Nhứt và ctv., 2013). Theo Cao Văn Thích (2008), khi ao nuôi cá tra đạt năng suất 300 tấn/ha/vụ, mỗi vụ nuôi sẽ thải ra ngoài môi trường khoảng 2.677 tấn bùn ướt (tương đương 937 tấn bùn khô). Nếu lượng bùn này được xả thải trực tiếp ra ngoài sẽ là nguy cơ ô nhiễm môi trường, phát sinh dịch bệnh, làm giảm tính bền vững của nghề nuôi cá tra (Trương Quốc Phú và ctv., 2012). Khi sản xuất được 1 tấn cá tra, cần 3,2-3,6 tấn thức ăn tự chế biến hoặc từ 1,5-1,6 tấn thức ăn công nghiệp (Huỳnh Thị Tú và ctv., 2006). Hiện nay, việc thay nước thường xuyên đã thải ra một lượng chất thải lớn chưa qua xử lý, có khả năng gây ô nhiễm môi trường nước (Lê Bảo Ngọc, 2004). Thức ăn thừa, chất thải của cá và một số thuốc/hóa chất sử dụng trong quá trình nuôi tạo thành một lượng lớn bùn đáy. Lượng bùn đáy này ảnh hưởng lớn đến chất lượng nước ao nuôi, sức khỏe cá nuôi và tác động lên môi trường xung quanh, làm ảnh hưởng đến sự bền vững của nghề nuôi (Võ Nam Sơn và ctv., 2015). Tuy nhiên, do tác động của dòng chảy, khả năng trao đổi nước giữa khu vực trong và ngoài không thường xuyên dẫn tới hiện tượng nước bị tù đọng, khó lưu thông và gây ô nhiễm môi trường nước cục bộ (Phạm Lê Mỹ Duyên và ctv., 2015). Hậu quả là không chỉ ảnh hưởng đến môi trường mà đời sống của hơn hai triệu người dân sinh sống trong khu vực có thể bị ảnh hưởng (Thu et al., 2011; Anh \& Giao, 2018). Bên cạnh đó, Tô Quang Toản (2016) đã chỉ ra rằng dù lưu lượng nước trung bình cả mùa mưa và mùa khô được gia tăng do tác động điều tiết của thủy điện ở thượng nguồn, tuy nhiên dòng chảy về hạ lưu thay đổi trái qui luật là rất bất lợi đến sản xuất nông nghiệp. Kết quả là xu thế lũ vừa và nhỏ sẽ xảy ra thường xuyên hơn trong khu vực, chất lượng nước biến động sẽ tác động lớn đến nghề nuôi trồng thủy sản. Do vậy, dòng chảy ở thượng nguồn có vai trò rất lớn trong sự phát triển kinh tế của khu vực, đặc biệt là ngành nông nghiệp, thủy sản (Tăng Đức Thắng \& Tô Quang Toản, 2016). Khi dòng chảy kém, lưu lượng nước ít sẽ tích tụ các hàm lượng dinh dưỡng trong nước và kéo dài, đặc biệt là sẽ ảnh hưởng đến khả năng tự làm sạch của thủy vực. Cùng với đó là do đặc tính hàm lượng phù sa, keo khoáng trong thủy vực cao sẽ mang lại những bất lợi rất lớn cho thủy vực như hàm lượng chất rắn lơ lửng cao, oxy hòa tan giảm thấp và mật độ vi sinh vật gia tăng làm cho nguồn nước cấp tại các sông, kênh dẫn rất dễ bị ô nhiễm cục bộ, ảnh hưởng trực tiếp đến nghề nuôi 
trồng thủy sản của vùng, đặc biệt là con cá tra - đối tượng kinh tế chủ lực. Việc theo dõi sự biến động, thay đổi các hàm lượng dinh dưỡng trong nguồn nước cấp ngoài tự nhiên theo thời gian, mùa vụ trong khu vực nuôi cá tra của vùng là hết sức cần thiết. Chính vì vậy, nghiên cứu về hàm lượng chất dinh dưỡng môi trường nước tự nhiên trong các khu vực nuôi cá tra tại tỉnh An Giang là cấp bách trong giai đoạn hiện nay. Kết quả nghiên cứu sẽ đưa ra những nhận định, cảnh báo để có biện pháp quản lý, xử lý phù hợp về chất lượng nước để hướng đến phát triển nghề nuôi cá tra bền vững của vùng và bảo vệ nguồn tài nguyên nước trong khu vực.

\section{VÂT LIỆU VÀ PHƯƠNG PHÁP NGHIẾN CÚU}

Bảng 1. Các điểm thu mẫu tại khu vục nuôi cá tra tỉnh An Giang

\begin{tabular}{|c|c|c|c|c|}
\hline \multirow{2}{*}{ STT Tên mẫu } & \multirow{2}{*}{ Điểm thu } & \multirow{2}{*}{ Nhóm thủy vực } & \multicolumn{2}{|c|}{ Vị trí } \\
\hline & & & Vĩ độ bắc (N) & Kinh độ đông (E) \\
\hline AG1 & Cồn Khánh Hòa & & $10^{\circ} 41.406^{\prime}$ & $105^{\circ} 11.704^{\prime}$ \\
\hline 02 AG2 & Vịnh Tre & Sông Hậu & $10^{\circ} 37.117^{\prime}$ & $105^{\circ} 12.574^{\prime}$ \\
\hline 03 AG3 & Bến đò Sơn Đốt & & $10^{\circ} 26.751^{\prime}$ & $105^{\circ} 23.408^{\prime}$ \\
\hline 04 AG4 & Kênh Tây An & & $10^{\circ} 20.502^{\prime}$ & $105^{\circ} 26.956^{\prime}$ \\
\hline 05 AG5 & Kênh Cái Sao 2 & Kênh cấp & $10^{\circ} 18.576^{\prime}$ & $105^{\circ} 26.122^{\prime}$ \\
\hline 06 AG6 & Kênh Ông Cò & & $10^{\circ} 19.438^{\prime}$ & $105^{\circ} 19.811^{\prime}$ \\
\hline
\end{tabular}

\subsection{Phương pháp thu, bảo quản và phân tích mẫu}

Mẫu nước, mẫu bùn được thu vào buổi sáng (từ 8 giờ đến 10 giờ) trong ngày, đại diện cho thủy vực tại các điểm thu và vận chuyển về phòng thí nghiệm để phân tích. Các chỉ tiêu theo dõi được phân tích tại

\subsection{Thời gian và địa điểm thu mẫu}

Mẫu nước tầng mặt và mẫu bùn tầng đáy được thu tại 3 điểm ở sông Hậu và 3 điểm thuộc các kênh cấp tại các khu vực nuôi cá tra thâm canh của tỉnh. Các điểm thu được chọn dựa trên nguồn nước cấp cho ao nuôi cá tra chịu sự ảnh hưởng và tác động trực tiếp bởi nghề nuôi cá tra của vùng. Đặc điểm vị trí thu mẫu ở thủy vực sông Hậu là có diện tích bề mặt rộng, lưu lượng nước lớn và có khả năng tự làm sạch nhanh so với các điểm thu ở kênh cấp là có diện tích nhỏ, lưu lượng nước kém và dễ biến động. Thời gian thu mẫu được thực hiện 4 đợt, tháng 3 (T3), tháng 6 (T6), tháng 9 (T9) và tháng 12 (T12).
Phòng Thí nghiệm Phân tích Chất lượng nước, Bộ môn Thủy sinh học Ứng dụng, Khoa Thủy sản, Trường Đại học Cần Thơ. Phương pháp thu mẫu và phân tích dựa theo phương pháp phân tích chuẩn American Public Health Association (APHA, 1995) (Bảng 2).

\section{Bảng 2. Phương pháp thu, bảo quản và phân tích mẫu}

\begin{tabular}{lll}
\hline Chỉ tiêu & Phương pháp thu mẫu & Phương pháp phân tích \\
\hline Nhiệt độ & Đo trực tiếp & Máy đo đa chỉ tiêu HANNA (HI9828) \\
pH & Đo trực tiếp & Máy đo đa chỉ tiêu HANNA (HI9828) \\
TSS & Trữ lạnh $\left(4^{\circ} \mathrm{C}\right)$ & PP Trọng lượng (2540-D,TSS) (APHA, 1995) \\
TAN & Trữ lạnh $\left(4^{\circ} \mathrm{C}\right)$ & Phenate, 4500-B (APHA, 1995) \\
Nitrate & Trữ lạnh $\left(4^{\circ} \mathrm{C}\right)$ & Salicylate, 4500-B (APHA, 2012) \\
Phosphate & Trữ lạnh $\left(4^{\circ} \mathrm{C}\right)$ & Methylene Blue, 4500-D (APHA, 1995) \\
TN nước & Trữ lạnh $\left(4^{\circ} \mathrm{C}\right)$ & Macro-Kjeldahl, 4500-B-N \\
ogr (APHA, 1995) \\
TN bùn đáy & Trữ lạnh $\left(4^{\circ} \mathrm{C}\right)$ & Macro-Kjeldahl, 4500-B-N \\
TP nước & Trữ lạnh $\left(4^{\circ} \mathrm{C}\right)$ & Persulfate, 4500-P-B(APHA, 2012) \\
TP bùn đáy & Trữ lạnh $\left(4^{\circ} \mathrm{C}\right)$ & Persulfate, 4500-P-B(APHA, 2012) \\
Chlorophyll- $a$ & Trữ lạnh $\left(4^{\circ} \mathrm{C}\right)$ & Chlorophyll, 10200-H (APHA, 1995) \\
\hline
\end{tabular}

\subsection{Xử lý số liệu}

Các số liệu được theo dõi, ghi nhận của các điểm thu qua các đợt thu mẫu bằng phần mềm Microsoft Excel. Chỉ tiêu môi trường, hàm lượng dinh dưỡng tại các điểm được tổng hợp, so sánh và nhận định sự thay đổi giữa hai nhóm thủy vực sông Hậu và kênh

cấp tự nhiên chịu ảnh hưởng của khu vực nuôi cá tra trong cùng một đợt hoặc giữa các đợt thu mẫu. Sự khác biệt trung bình giữa hai nhóm thủy vực được xử lý ANOVA một nhân tố với phép thử Duncan ở mức ý nghĩa $\mathrm{p}=0,05$ bằng phần mềm SAS 9.1 (SAS Institute, Cary, NC, USA). Hàm lượng chlorophyll$a$ sẽ được xử lý tương quan Pearson bằng phần mềm 
SPSS 22.0 để đánh giá mức độ tương quan với các yếu tố dinh dưỡng trong nước. Các chỉ số phân tích sẽ được so sánh với quy chuẩn quốc gia về chất lượng nguồn nước cũng như các chỉ số dùng trong nuôi trồng thủy sản, đặc biệt là phục vụ nuôi cá tra.

\section{KẾT QUẢ VÀ THẢO LUẬN}

\subsection{Nhiệt độ và $p H$}

Nhiệt độ tại các điểm thu thuộc hai nhóm thủy vực có giá trị dao động từ $28,6-32,3^{\circ} \mathrm{C}$ qua các đợt thu mẫu. Kết quả ghi nhận nhiệt độ nước có xu hướng dao động tương đồng với nhiệt độ của vùng khí hậu gió mùa xích đạo, tương ứng với đặc điểm vị trí địa lí của vùng. Vào mùa khô (T3) và thời điểm giao mùa (T6), nhiệt độ nước có giá trị trung bình tại các điểm thu cao hơn các tháng còn lại. Nhiệt độ tại nhóm kênh cấp nội đồng có giá trị cao hơn và khác biệt có ý nghĩa so với nhóm thủy vực sông Hậu $(\mathrm{p}<0,05)$ vào mùa khô $(\mathrm{T} 3)$. Tuy nhiên, ở các thời điểm còn lại thì có giá trị tương đồng nhau $(\mathrm{p}>0,05)$. Điều này cho thấy vào mùa khô, nắng nóng nhiều hơn nên thủy vực kênh cấp nội đồng với các đặc điểm là dòng chảy kém, lưu lượng nước ít nên thủy vực rất dễ bị ảnh hưởng bởi ánh nắng mặt trời. Vào T12, nhiệt độ ở các thủy vực có giá trị trung bình giảm thấp là do khí hậu trong khu vực đã vào cuối mùa mưa và trời lập đông nên nhiệt độ không khí lạnh và ảnh hưởng đến nhiệt độ nước. Trần Trung Giang và ctv. (2020) ghi nhận nhiệt độ tại các điểm thu tại cửa sông Hậu và dọc tuyến sông Mỹ Thanh có giá trị nhiệt độ dao động $27,2-32,6^{\circ} \mathrm{C}$ từ tháng 1 đến tháng 6 trong năm. Báo cáo kết quả quan trắc môi trường tỉnh An Giang (Trung tâm Quan trắc và Kỹ thuật Tài nguyên - Môi trường An Giang, 2018) khi quan trắc chất lượng nước mặt chịu tác động từ khu vực nuôi thủy sản của vùng nuôii, nhiệt độ ở các thủy vực dao động từ $28,4-30,2^{\circ} \mathrm{C}$. Trên địa bàn thành phố Cần Thơ, thời gian từ năm 2016-2020, nhiệt độ trên sông tại địa bàn dao động trung bình khoảng $29,1^{\circ} \mathrm{C}$, thích hợp cho nuôi trồng thủy sản. Nhiệt độ thích hợp của cá tra, cá chim trắng, rô phi, trắm cỏ, tôm sinh trưởng và phát triển từ $28-30^{\circ} \mathrm{C}$ (Chi cục Thủy sản Cần Thơ, 2020). Theo QCVN 0220:2014/BNNPTNT, chất lượng nước cấp vào ao nuôi và nước ao nuôi cá tra có nhiệt độ trung bình từ $25-32^{\circ} \mathrm{C}$ sẽ giúp cho cá tra tăng trưởng và phát triển tốt.

Bảng 3. Nhiệt độ và pH

\begin{tabular}{ccccc}
\hline \multirow{2}{*}{ Tháng } & \multicolumn{2}{c}{ Nhiệt độ $\left({ }^{\mathbf{0}} \mathbf{C}\right)$} & \multicolumn{2}{c}{ pH } \\
\cline { 2 - 5 } & Sông Hậu & Kênh cấp & Sông Hậu & Kênh cấp \\
\hline T3 & $30,9 \pm 0,1^{\mathrm{a}}$ & $31,8 \pm 0,1^{\mathrm{b}}$ & $7,2 \pm 0,2^{\mathrm{a}}$ & $7,1 \pm 0,2^{\mathrm{a}}$ \\
T6 & $31,7 \pm 0,3^{\mathrm{a}}$ & $31,7 \pm 0,6^{\mathrm{a}}$ & $7,3 \pm 0,2^{\mathrm{a}}$ & $7,2 \pm 0,1^{\mathrm{a}}$ \\
T9 & $30,8 \pm 0,5^{\mathrm{a}}$ & $30,5 \pm 0,3^{\mathrm{a}}$ & $7,1 \pm 0,1^{\mathrm{a}}$ & $6,9 \pm 0,1^{\mathrm{a}}$ \\
T12 & $28,7 \pm 0,1^{\mathrm{a}}$ & $28,8 \pm 0,2^{\mathrm{a}}$ & $7,4 \pm 0,2^{\mathrm{b}}$ & $6,9 \pm 0,2^{\mathrm{a}}$ \\
\hline
\end{tabular}

*Các giá trị trung bình \pm độ lệch chuẩn trong cùng một dòng có ký tụ giống nhau thì khác biệt không có ý nghĩa thống kê $(p>0,05)$

Kết quả ghi nhận giá trị pH ở các điểm thu ít biến động qua các đợt thu mẫu cũng như tại các điểm thu mẫu, dao động từ $6,7-7,5$ ở các điểm thu và trung bình là $7,2 \pm 0,2$ và $7,0 \pm 0,1$ ở nhóm thủy vực sông Hậu và kênh cấp, tương ứng. Giá trị $\mathrm{pH}$ vẫn trong giới hạn cho phép là 6,5-8,5. Giá trị giới hạn các thông số trong nước mặt dùng cho mục đích bảo vệ đời sống thủy sinh QCVN 38:2011/BTNMT và phù hợp với QCVN 02-20:2014/BNNPTNT về cơ sở nuôi cá tra (Pangasianodon hypophthalmus Sauvage, 1878) trong ao - điều kiện bảo đảm vệ sinh thú $\mathrm{y}$, bảo vệ môi trường và an toàn thực phẩm khi sử dụng chất lượng nước cấp vào ao nuôi và nước ao nuôi cá tra thì $\mathrm{pH}$ có giá trị từ 7-9. Báo cáo kết quả quan trắc môi trường tỉnh An Giang (Trung tâm Quan trắc và Kỹ thuật Tài nguyên - Môi trường An Giang, 2018) khi quan trắc chất lượng nước mặt chịu tác động từ khu vực nuôi thủy sản của vùng nuôi, $\mathrm{pH}$ ở các thủy vực dao động từ $6,84-7,18$. Như vậy, nhiệt độ và giá trị $\mathrm{pH}$ của nguồn nước tại các điểm thu ít bị biến động và phù hợp cho sự phát triển của cá tra.

\subsection{Tổng chất rắn lơ lửng (TSS) và tổng đạm ammonia (TAN)}

Kết quả ghi nhận TSS ở cả hai nhóm thủy vực có $\mathrm{xu}$ hướng giảm vào $\mathrm{T} 6$ và $\mathrm{T} 9$ của thời gian thu mẫu. Điều này là do vào mùa mưa, mực nước dâng cao, sức tải của thủy vực lớn hơn nên làm cho lượng TSS trong nước có xu hướng giảm thấp. Vào T12, TSS trong nước có giá trị cao hơn so với các tháng còn lại, đạt giá trị trung bình là $84 \pm 46,1 \mathrm{mg} / \mathrm{L}$ ở sông Hậu và $80,0 \pm 61,6$ mg/L ở nhóm kênh cấp, tuy nhiên không tìm thấy sự khác biệt có ý nghĩa thống kê giữa hai nhóm thủy vực $(\mathrm{p}>0,05)$. Điều này là do vào T12, cuối mùa mưa và bắt đầu mùa khô nên dòng chảy bắt đầu kém lại, lưu lượng nước ít đi và thời gian trước đó là mưa, lũ kéo dài đã làm cho hàm 
lượng TSS tăng cao trong thủy vực. Theo kêt quả khi so sánh giữa hai nhóm thủy vực vào mùa khô (T3 và T6), TSS ở nhóm thủy vực kênh cấp có giá trị cao hơn 1,6 lần so với thủy vực sông Hậu vào tháng 3 và cao gấp 1,2 lần vào tháng 6 . Điều này cho thấy đối với thủy vực lớn (sông Hậu) có sức tải thủy vực lớn hơn nên việc ảnh hưởng của việc nuôi cá tra ít bị tác động, hàm lượng chất rắn lơ lửng trong nước ít bị tích tụ. Riêng đối với thủy vực kênh cấp nội đồng vào mùa khô, lưu lượng nước kém và việc nuôi cá tra trong khu vực đã ít nhiều ảnh hưởng đến nguồn nước, làm cho hàm lượng chất rắn lơ lửng có xu hướng tăng cao, tích tụ lại trong thủy vực.

Trần Trung Giang và ctv. (2020) cũng đã nhận định hàm lượng TSS có $x u$ hướng giảm vào thời điểm giao mùa Khô-Mưa và biến động cao vào các mùa còn lại trong năm tại các thủy vực sông tự nhiên. Điều này cho thấy rằng dòng triều cũng như lưu lượng nước ảnh hưởng rất lớn đến hàm lượng TSS trong nước. Báo cáo kết quả quan trắc môi trường tỉnh An Giang (Trung tâm Quan trắc và Kỹ thuật Tài nguyên - Môi trường An Giang, 2018) khi quan trắc chất lượng nước mặt chịu tác động từ khu vực nuôi thủy sản của vùng nuôi cho thấy hàm lượng TSS ở các thủy vực dao động từ 39-71 mg/L. Giá trị giới hạn của TSS trong nước mặt dùng cho mục đích bảo vệ đời sống thủy sinh vật được quy định theo QCVN 38:2011/BTNMT có giá trị là $100 \mathrm{mg} / \mathrm{L}$. TSS trong nghiên cứu hiện tại có giá trị thấp và phù hợp so với quy chuẩn. Tuy nhiên cũng cần phải chú ý khi lấy nước cấp vào mùa khô và ở các kênh cấp nội đồng vì hàm lượng TSS rất dễ biến động và tăng cao.

Hàm lượng TAN tại hai nhóm thủy vực dao động từ $0,06-1,12 \mathrm{mg} / \mathrm{L}$ qua các đợt thu mẫu. Kết quả ghi nhận hàm lượng TAN có giá trị cao và khác biệt có ý nghĩa thống kê ở nhóm thủy vực kênh cấp so với nhóm thủy vực sông Hậu $(\mathrm{p}<0,05)$. Điều này cho thấy việc nuôi cá tra thâm canh trong khu vực đã ít nhiều ảnh hưởng đến hàm lượng TAN trong nước tự nhiên của thủy vực. Hàm lượng TAN có xu hướng giảm rất rõ ở nhóm thủy vực sông Hậu, đối với nhóm thủy vực kênh cấp thì có giá trị ngược lại, tăng lên rất cao. Hàm lượng TAN trong nước khi ở giữa và thời gian sau của vụ nuôi có xu hướng tăng cao (T3, T6), đặc biệt là vào mùa khô, lưu lượng nước kém. Theo quy trình kỹ thuật nuôi thâm canh cá Tra (Bộ Thủy sản, 2014), lịch thời vụ thả giống cá tra của vùng bắt đầu từ tháng 2 hoặc tháng 3 hàng năm. Chính vì vậy, việc trao đổi nguồn nước nuôi đã ít nhiều làm biến đổi hàm lượng TAN trong nước, đặc biệt là nhóm thủy vực kênh cấp trong nội đồng. Do là thủy vực có lưu lượng kém, dòng chảy yếu, sự tích tụ nguồn thải từ nội động nên hàm lượng TAN trong nước có xu hướng tăng cao và đạt giá trị trung bình $1,12 \pm 0,59 \mathrm{mg} / \mathrm{L}$ vào $T 6$ và $1,05 \pm 0,54 \mathrm{mg} / \mathrm{L}$ vào T12 của đợt thu mẫu. Hàm lượng TAN ở sông Hậu có giá trị thấp và có khuynh hướng giảm theo thời gian thu mẫu. Do đây là thủy vực có lưu lượng lớn, nước chảy xiết vào mùa mưa, lũ nên đã làm cho hàm lượng TAN trong nước tự nhiên khu vực nuôi cá tra có xu hướng giảm thấp.

Bảng 4. TSS và TAN

\begin{tabular}{ccccc}
\hline \multirow{2}{*}{ Tháng } & TSS (mg/L) & \multicolumn{2}{c}{ TAN (mg/L) } \\
\cline { 2 - 5 } & Sông Hậu & Kênh cấp & Sông Hậu & Kênh cấp \\
\hline T3 & $30,7 \pm 11,0^{\mathrm{a}}$ & $48,3 \pm 31,8^{\mathrm{a}}$ & $0,60 \pm 0,69^{\mathrm{a}}$ & $0,78 \pm 0,70^{\mathrm{a}}$ \\
T6 & $24,7 \pm 5,0^{\mathrm{a}}$ & $30,3 \pm 15,3^{\mathrm{a}}$ & $0,15 \pm 0,08^{\mathrm{a}}$ & $1,12 \pm 0,59^{\mathrm{b}}$ \\
T9 & $37,3 \pm 43,9^{\mathrm{a}}$ & $22,3 \pm 7,1^{\mathrm{a}}$ & $0,08 \pm 0,05^{\mathrm{a}}$ & $0,06 \pm 0,07^{\mathrm{a}}$ \\
T12 & $84,0 \pm 46,1^{\mathrm{a}}$ & $80,0 \pm 61,6^{\mathrm{a}}$ & $0,13 \pm 0,03^{\mathrm{a}}$ & $1,05 \pm 0,54^{\mathrm{b}}$ \\
\hline
\end{tabular}

* Các giá trị trung bình độ lệch chuẩn trong cùng một dòng có ký tụ giống nhau thì khác biệt không có ý nghĩa thống kê ( $p>0,05)$

Tổng đạm ammonia là bao gồm dạng ion ammonium $\left(\mathrm{NH}_{4}{ }^{+}\right.$, nguồn dinh dưỡng thực vật hấp thụ) và ammoniac $\left(\mathrm{NH}_{3}\right.$, gây độc đối với động vật thủy sinh); trạng thái cân bằng của hai dạng này thay đổi tùy thuộc vào giá trị $\mathrm{pH}$, nhiệt độ và độ mặn của nước (Boyd \& Tucker, 1998). Ở độ pH 7,5-8,0, cá tra tăng trưởng cao hơn ở nghiệm thức có hàm lượng TAN là $6,5 \mathrm{mg} / \mathrm{L}$ so với đối chứng và $10 \mathrm{mg} / \mathrm{L}$ (Phạm Quốc Nguyên và ctv., 2015). Theo Nguyễn Hữu Lộc (2009), việc ao nuôi cá tra thâm canh được thay nước thường xuyên, liên tục nhưng về cuối vụ thì TAN vẫn cao gấp 5 lần so với ao nuôi tôm thâm canh và gấp 10 lần trong các ao nuôi thủy sản khác. Cá tra được nuôi ở mật độ cao nên sản phẩm thải của cá và thức ăn dư thừa làm cho $\mathrm{TAN}$ có thể đạt đến 9,19 mg/L (Phạm Quốc Nguyên \& Lê Hồng Y, 2011). Chính vì điều này đã làm cho hàm lượng TAN có xu hướng tăng cao theo thời gian nuôi ở cả nguồn nước trong ao và nguồn nước bên ngoài chịu tác động. Theo Trần Trung Giang và ctv. (2020) khi so sánh giữa hai loại hình thủy vực, hàm lượng TAN ở các thủy vực sông nội đồng cao hơn vùng cửa sông, nhưng sự chênh lệch không cao qua 6 tháng đầu năm tại khu vực tự nhiên tỉnh Sóc Trăng. Theo 
QCVN 08-MT:2015/BTNMT, hàm lượng TAN cho phép ở tầng nước mặt là $0,3 \mathrm{mg} / \mathrm{L}$. Kết quả nghiên cứu hiện tại có giá trị tương đồng với báo cáo kết quả khi quan trắc chất lượng nước mặt chịu tác động từ khu vực nuôi thủy sản của vùng nuôi tỉnh $A n$ Giang thì hàm lượng TAN ở các thủy vực dao động từ $0,045-1,660 \mathrm{mg} / \mathrm{L}$ (Trung tâm Quan trắc và $\mathrm{Kỹ}$ thuật Tài nguyên - Môi trường An Giang, 2018). Như vậy, với kết quả ghi nhận được thì hàm lượng TAN có giá trị cao hơn so với quy chuẩn nhưng so với việc dùng nguồn nước để sử dụng làm nước cấp cho ao cá tra thì ít chịu ảnh hưởng. Tuy nhiên cũng cần phải theo dõi diễn biến và xử lý kịp thời khi sử dụng nguồn nước làm nguồn nước cấp phục vụ ao nuôi cá tra thâm canh của vùng.

\subsection{Nitrate và Phosphate}

Kết quả ghi nhận hàm lượng nitrate trong nước vẫn còn ở mức thấp, ít ảnh hưởng đến thủy vực. Hàm lượng nitrate có xu hướng giảm vào mùa mưa (T6 và $T 9)$ và tăng vào mùa khô (T12 và $T 3)$ ở cả hai nhóm thủy vực. Tuy nhiên, hàm lượng nitrate thấp ở các điểm qua thời gian thu mẫu và không có sự khác biệt có ý nghĩa thống kê ở hai nhóm thủy vực $(\mathrm{p}>0,05)$. Hàm lượng nitrate dao động từ 0,003 $0,647 \mathrm{mg} / \mathrm{L}$ qua thời gian thu mẫu. Theo Trần Trung Giang và ctv. (2020), hàm lượng nitrate có giá trị dao động từ $0,02-0,97 \mathrm{mg} / \mathrm{L}$ ở sông Hậu và dọc tuyến sông nội đồng, và hàm lượng nitrate trung bình ở các điểm thu mẫu có biến động nhưng ở mức thấp và có thể sử dụng cho sinh hoạt và các hoạt động nông nghiệp, thủy sản. Theo tiêu chuẩn của QCVN 08-MT:2015/BTNMT về giá trị giới hạn của các thông số chất lượng nước mặt được quy định, hàm lượng nitrate đạt giới hạn cho phép là nhỏ hơn $2 \mathrm{mg} / \mathrm{L}$. Hàm lượng nitrate ghi nhận được ở sông Hậu trong 10 năm (2009-2018) dao động trung bình từ $0,04 \pm 0,03$ đến $0,10 \pm 0,04 \mathrm{mg} / \mathrm{L}$, và chất lượng nước sông rạch của tỉnh An Giang có hàm lượng nitrate dao động từ $0,31 \pm 0,30$ đến $0,58 \pm 0,64 \mathrm{mg} / \mathrm{L}$ (Ly \& Giao, 2018; Nguyen Thanh Giao, 2020). Boyd (1998) cho rằng hàm lượng nitrate trong nước thích hợp cho nuôi trồng thủy sản từ $0,2-10 \mathrm{mg} / \mathrm{L}$. Nguyễn Thị Kim Liên và ctv. (2016) cho rằng hàm lượng nitrate dọc tuyến sông nhánh và sông chính của sông Hậu có giá trị dao động 0,002-0,395 mg/L, trung bình $0,11 \pm 0,07 \mathrm{mg} / \mathrm{L}$. Hàm lượng nitrate vùng đầu nguồn và giữa nguồn của sông Hậu không khác biệt qua các đợt khảo sát ( $\mathrm{p}>0,05)$. Tuy nhiên, hàm lượng nitrate ở vùng cuối nguồn cao hơn vào mùa khô và thấp vào mùa mưa. Kết quả hiện tại có kết quả khá tương đồng với nghiên cứu của Nguyễn Thị Kim Liên và ctv. (2016) là khi vào mùa mưa, hàm lượng nitrate trên sông giảm thấp so với thời gian trước đó là mùa khô ở cả hai nhóm thủy vực sông lớn và kênh cấp. Vũ Ngọc Út và ctv. (2013) cũng đã nhận định hàm lượng nitrate trên sông Cổ Chiên có sự biến động khá cao qua các tháng khảo sát nhưng có khuynh hướng tăng vào các tháng mùa khô, tập trung vào các tháng 3 đến tháng 5 và giảm thấp vào mùa mưa. Như vậy có thể thấy rằng hàm lượng nitrate ở các thủy vực tự nhiên có giá trị thấp, kể cả trong khu vực nuôi cá tra vào mùa khô và đầu mùa mưa. Vì đối với thủy vực tự nhiên, việc oxy hóa hay chuyển hóa đạm sang hàm lượng nitrate rất kém, một phần vì hàm lượng oxy hay các phản ứng để oxy hóa đạm rất ít, một phần vì mật độ vi khuẩn để chuyển hóa đạm sang nitrate trong nước rất thấp. Bên cạnh đó, đạm nitrate là một dạng đạm mà thực vật thủy sinh có thể hấp thụ trực tiếp và dễ dàng để làm nguồn dinh dưỡng. Chính vì những điều này đã làm cho thủy vực tự nhiên luôn có hàm lượng nitrate thấp.

\section{Bảng 5. Nitrate và Phosphate}

\begin{tabular}{ccccc}
\hline \multirow{2}{*}{ Tháng } & \multicolumn{2}{c}{ Nitrate(mg/L) } & \multicolumn{2}{c}{ Phosphate $(\mathbf{m g} / \mathbf{L})$} \\
\cline { 2 - 5 } & Sông Hậu & Kênh cấp & Sông Hậu & Kênh cấp \\
\hline T3 & $0,53 \pm 0,11^{\mathrm{a}}$ & $0,37 \pm 0,25^{\mathrm{a}}$ & $0,06 \pm 0,06^{\mathrm{a}}$ & $0,08 \pm 0,09^{\mathrm{a}}$ \\
T6 & $0,20 \pm 0,04^{\mathrm{a}}$ & $0,22 \pm 0,04^{\mathrm{a}}$ & $0,12 \pm 0,07^{\mathrm{a}}$ & $0,15 \pm 0,06^{\mathrm{a}}$ \\
T9 & $0,03 \pm 0,02^{\mathrm{a}}$ & $0,03 \pm 0,01^{\mathrm{a}}$ & $0,05 \pm 0,01^{\mathrm{a}}$ & $0,18 \pm 0,06^{\mathrm{b}}$ \\
T12 & $0,25 \pm 0,02^{\mathrm{a}}$ & $0,23 \pm 0,07^{\mathrm{a}}$ & $0,37 \pm 0,30^{\mathrm{a}}$ & $1,11 \pm 0,59^{\mathrm{a}}$ \\
\hline
\end{tabular}

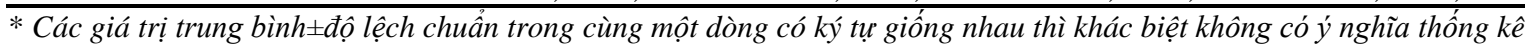
$(p>0,05)$

Theo QCVN 08-MT:2015/BTNMT, giá trị giới hạn của hàm lượng phosphate trong chất lượng nước sử dụng cho mục đích cấp nước sinh hoạt, bảo tồn động thực vật thủy sinh và các mục đích khác trên tầng mặt có giá trị giới hạn là $0,1 \mathrm{mg} / \mathrm{L}$. Kết quả ghi nhận hàm lượng phosphate trong nước có giá trị trung bình thấp và biến động ở hai nhóm thủy vực vào $\mathrm{T} 3, \mathrm{~T} 6$ và $\mathrm{T} 9$. Vào $\mathrm{T} 12$, hàm lượng phosphate có giá trị trung bình cao và biến động ở các điểm thu mẫu. Hàm lượng phosphate đạt cao nhất ở nhóm thuỷ vực kênh cấp với giá trị là $1,11 \pm 0,59 \mathrm{mg} / \mathrm{L}$ và ở sông Hậu là $0,37 \pm 0,30 \mathrm{mg} / \mathrm{L}$; cao gấp 3,7 và 11,1 lần so với QCVN 08-MT:2015/BTNMT ở kênh cấp và sông Hậu tương ứng. Phosphate là thành phần 
chủ yếu để hình thành nên diệp lục tố của thực vật thủy sinh nên đây sẽ là nguồn dinh dưỡng giúp thực vật hấp thu và tăng trưởng (Nguyễn Phú Hòa, 2012). Khi hàm lượng phosphate trong nước quá cao sẽ rất dễ làm cho thực vật phù du phát triển, gây hiện tượng tảo nở hoa, làm ô nhiễm nguồn nước trong thủy vực. Điều này cho thấy rằng tại các khu vực nuôi cá tra thâm canh đã ảnh hưởng đến hàm lượng phosohate trong nước tự nhiên, đặc biệt là các kênh cấp nội đồng. Vào tháng 12 , đầu mùa khô cũng là thời gian thu hoạch cá trong ao, hoặc những ao thu hoạch bắt đều tiến hành xử lý nền đáy ao để chuẩn bị vụ mùa mới. Vì sau thời gian nuôi từ 8-10 tháng, cá đã đạt chất lượng thương phẩm có thể tiến hành thu hoạch toàn bộ cá nuôi trong ao (Bộ Thủy sản, 2014). Chính những điều này đã làm cho hàm lượng phosphate trong nước tự nhiên tăng cao ở cả hai nhóm thủy vực, đặc biệt là ở các kênh cấp nội đồng, chịu xả thải, trao đổi nguồn nước trực tiếp và liên tục từ các ao nuôi. Trần Trung Giang và ctv. (2020) lấy mẫu ở thủy vực vùng cửa sông khu vực nuôi tôm tỉnh Sóc Trăng, kết quả cho thấy hàm lượng phosphate có giá trị trung bình là $0,29 \pm 0,18 \mathrm{mg} / \mathrm{L}$ qua 6 tháng thu mẫu. Hàm lượng phosphate ở các thủy vực tự nhiên trong khu vực nuôi thủy sản của vùng nuôi tỉnh An Giang dao động từ $0,077-0,804$ mg/L (Trung tâm Quan trắc và Kỹ thuật Tài nguyên - Môi trường An Giang, 2018). Theo báo cáo tổng kết quan trắc môi trường phục vụ nuôi trồng thủy sản trên địa bàn thành phố Cần Thơ, hàm lượng phosphate trên sông Hậu trong năm 5 từ năm 20162020 tại các khu vực Thốt Nốt, Vĩnh Thạnh, Ô Môn đều cao dao động trong khoảng $0,0-2,9 \mathrm{mg} / \mathrm{L}$, với trung bình là $0,86 \mathrm{mg} / \mathrm{L}$ cao hơn so với theo $\mathrm{QCVN}$ 08-MT:2015/BTNMT (Chi cục Thủy sản Cần Thơ,
2020). Nghiên cứu của Thái Thị Nguyên (2013), chất lượng nước trên tuyến sông Hậu có hàm lượng phosphate dao động từ $0,017-0,415 \mathrm{mg} / \mathrm{L}$. Như vậy, so với kết quả nghiên cứu này hàm lượng phosphate tại các điểm thu vào $T 3, T 6$ và $T 9$ còn thấp, ít ảnh hưởng đến việc lấy nguồn nước sử dụng cho nuôi cá tra trong vùng. Riêng vào $\mathrm{T} 12$, khi sử dụng nguồn nước cấp vào ao tại các điểm thu mẫu cần chú ý đến hàm lượng phosphate có trong nước và phải có những biện pháp xử lý trước khi đưa vào ao nuôi.

\section{4. $T N$ và $T P$ trong nước}

Kết quả ghi nhận hàm lượng $\mathrm{TN}$ trung bình ở nhóm kênh cấp có giá trị cao hơn so với nhóm sông Hậu $(p<0,05)$. Hàm lượng $\mathrm{TN}$ trung bình ở nhóm sông Hậu là $1,55 \pm 0,54 \mathrm{mg} / \mathrm{L}$ và ở nhóm kênh cấp là $2,77 \pm 0,65 \mathrm{mg} / \mathrm{L}$ qua các đợt thu mẫu. Vào T12, hàm lượng TN trung bình ở nhóm kênh cấp cao gấp 3,8 lần so với nhóm sông Hậu. Hàm lượng $\mathrm{TP}$ ghi nhận được cũng khá biến động giữa các điểm qua thời gian thu mẫu. Hàm lượng TP dao động từ 0,08-3,34 $\mathrm{mg} / \mathrm{L}$ tại các điểm thu. Kết quả cũng ghi nhận hàm lượng $\mathrm{TP}$ vào $\mathrm{T} 12$ ở nhóm kênh cấp có giá trị cao, gấp 1,4 lần so với nhóm sông Hậu $(\mathrm{p}<0,05)$. Nhìn chung, kết quả ghi nhận hàm lượng $\mathrm{TN}$ và $\mathrm{TP}$ trong nước tại các điểm thu thuộc nhóm kênh cấp có giá trị cao hơn so với các điểm thu thuộc nhóm sông Hậu $(\mathrm{p}<0,05)$. Đặc biệt là vào $\mathrm{T} 12$ và $\mathrm{T} 3$, thời điểm mùa khô trong năm. Điều này cho thấy đối với các thủy vực kênh rạch nhỏ hẹp, lưu lượng nước kém, dễ tù đọng và sâu trong nội đồng có khả năng tích lũy và hòa tan hàm lượng dinh dưỡng $T N$ và $T P$ trong nước cao hơn so với thủy vực có lưu lượng lớn và nước chảy mạnh như sông Hậu.

\section{Bảng 6. TN và TP trong nước}

\begin{tabular}{ccrrr}
\hline \multirow{2}{*}{ Tháng } & TN $(\mathbf{m g} / \mathbf{L})$ & \multicolumn{2}{c}{ TP $(\mathbf{m g} / \mathbf{L})$} \\
\cline { 2 - 5 } & Sông Hậu & Kênh cấp & Sông Hậu & Kênh cấp \\
\hline T3 & $2,4 \pm 1,0^{\mathrm{a}}$ & $2,7 \pm 0,7^{\mathrm{a}}$ & $1,7 \pm 0,6^{\mathrm{a}}$ & $2,0 \pm 1,0^{\mathrm{a}}$ \\
T6 & $1,2 \pm 0,1^{\mathrm{a}}$ & $3,1 \pm 0,5^{\mathrm{b}}$ & $2,5 \pm 0,7^{\mathrm{a}}$ & $1,4 \pm 0,6^{\mathrm{a}}$ \\
T9 & $1,7 \pm 0,8^{\mathrm{a}}$ & $1,7 \pm 0,8^{\mathrm{a}}$ & $2,1 \pm 0,3^{\mathrm{b}}$ & $1,4 \pm 0,3^{\mathrm{a}}$ \\
T12 & $0,9 \pm 0,2^{\mathrm{a}}$ & $3,5 \pm 0,6^{\mathrm{b}}$ & $1,9 \pm 0,1^{\mathrm{a}}$ & $2,5 \pm 0,3^{\mathrm{b}}$ \\
\hline
\end{tabular}

* Các giá trị trung bình土độ lệch chuẩn trong cùng một dòng có ký tụ giống nhau thì khác biệt không có ý nghĩa thống kê ( $p>0,05$ )

Vị trí các điểm thu mẫu là chịu sự tác động trực tiếp của nghề nuôi cá tra trong vùng. Vì vậy, kết quả cũng đã chỉ ra được môi trường nước tự nhiên, đặc biệt là các kênh cấp nội đồng đã chịu tác động từ các hoạt động xung quanh, bao gồm xả thải sinh hoạt, nông nghiệp và đặc biệt là hoạt động nuôi cá tra trong khu vực. Theo Trần Thị Thanh Thủy và Đặng Thị Thúy Hạt (2017), nguyên nhân làm lượng phosphate lớn trong các mẫu nước mặt là do các khu vực tự nhiên gần đồng ruộng, ỗ nhiễm chủ yếu xuất phát từ hóa chất sử dụng trong canh tác nông nghiệp: phân bón, thuốc bảo vệ thực vật, thuốc trừ sâu,... Lê Hoàng Nam (2017) cho rằng hàm lượng $\mathrm{TN}$ phụ thuộc vào sự phát triển của tảo, lượng chất thải cá, thức ăn dư thừa,... nên thường hàm lượng $\mathrm{TN}$ sẽ tăng dần đến cuối vụ nuôi vì càng gần về cuối vụ nuôi 
lượng chất thải tích lũy sẽ nhiều. Trường hợp những ao nuôi từ tháng 6 trở lên được thay nước hầu như mỗi ngày nên hàm lượng chất ô nhiễm trong ao giảm xuống đáng kể và sự biến động hàm lượng $\mathrm{TN}$ trong ao nuôi không lớn. Bộ Thủy sản (2014) yêu cầu đối với ao nuôi cá tra thâm canh cần thay nước ao nuôi mỗi ngày khoảng 25-30\% lượng nước ao. Chính vì những điều này đã làm cho môi trường nước tự nhiên xung quanh khu vực ao nuôi rất dễ bị tác động. Theo Nguyễn Thị Kim Liên và ctv. (2016), nguồn nước chịu ảnh hưởng trực tiếp của nghề nuôi trồng thủy sản chủ yếu là nuôi cá tra trong ao đất có hàm lượng $\mathrm{TN}$ có sự chênh lệch tương đối cao và biến động trong khoảng 0,31-2,57 $\mathrm{mg} / \mathrm{L}$, trung bình $1,17 \pm 0,6 \mathrm{mg} / \mathrm{L}$. Hàm lượng TN ở các khu vực khảo sát vào mùa khô cao hơn mùa mưa ở cả sông chính và sông nhánh. Tác giả cũng nhận định nhóm thủy vực bị ảnh hưởng trực tiếp bởi nước thải thủy sản có TN đạt giá trị cao nhất trong các nhóm chịu ảnh hưởng và có biên độ cao vào mùa khô so với mùa mưa. Tại các điểm thu mẫu thuộc khu vực nuôi trồng thủy sản trên sông nhánh cũng có TP đạt khá cao do thường xuyên tiếp nhận lượng lớn chất thải của cá nên có TP đạt khá cao vào mùa khô. Theo Boyd \& Green (2002), để hạn chế tối đa khả năng gây phú dưỡng nguồn nước, TN không được vượt quá 3,0 $\mathrm{mg} / \mathrm{L}$. Khi TN cao hơn $1,7 \mathrm{mg} / \mathrm{L}$, khả năng gây phú dưỡng nguồn nước rất cao (Campbell, 2009). Nghiên cứu của Vũ Ngọc Út và ctv. (2013) cũng cho thấy TP trên sông Cổ Chiên thuộc sông Tiền đạt giá trị cao vào giai đoạn mùa khô và dao động từ 0,108 $4,873 \mathrm{mg} / \mathrm{L}$. Theo Boyd \& Green (2002), nếu hàm lượng TP trong nước lớn hơn $0,1 \mathrm{mg} / \mathrm{L}$, khả năng phú dưỡng sẽ rất dễ xảy ra. Qua đó cho thấy hàm lượng $\mathrm{TN}$ và $\mathrm{TP}$ trong nước ở nhóm thủy vực kênh cấp có giá trị cao hơn so với các điểm thu nhóm thủy vực sông Hậu nhưng vẫn còn ở mức thấp so với các yêu cầu trong nuôi trồng thủy sản. Vì vậy, khi sử dụng nguồn nước cần phải kiểm tra các hàm lượng dinh dưỡng để tránh trường hợp ô nhiễm dinh dưỡng, tảo nở hoa khi hàm lượng $\mathrm{TN}$, $\mathrm{TP}$ tăng cao vào mùa khô và vượt ngưỡng trong thủy vực.

\subsection{TN và $T P$ trong bùn đáy}

Kết quả phân tích bùn đáy ở hai nhóm thủy vực cho thấy hàm lượng $\mathrm{TN}$ và $\mathrm{TP}$ bùn đáy ở thủy vực kênh cấp có giá trị cao và có ý nghĩa thống kê so với thủy vực sông Hậu $(\mathrm{p}<0,05)$. Hàm lượng $\mathrm{TN}$ có giá trị trung bình là $0,8 \pm 0,4 \mathrm{mg} / \mathrm{g}$ ở thủy vực sông Hậu và là $1,2 \pm 0,5 \mathrm{mg} / \mathrm{g}$ ở thủy vực kênh cấp qua các đợt thu mẫu. Hàm lượng $\mathrm{TN}$ ở kênh cấp có giá trị cao từ 1,3-1,7 lần so với thủy vực sông Hậu. Hàm lượng TP có giá trị trung bình từ 1,9-2,5 mg/g ở các điểm qua thời gian thu mẫu. Kết quả cũng cho thấy hàm lượng TP ở thủy vực kênh cấp có giá trị cao hơn so với nhóm thủy vực sông Hậu và khác biệt có ý nghĩa thống kê vào $\mathrm{T} 6$ và $\mathrm{T} 9$ của thời gian thu mẫu.

Bảng 7. TN và TP trong bùn đáy

\begin{tabular}{cccrr}
\hline \multirow{2}{*}{ Tháng } & TN $(\mathbf{m g} / \mathbf{g})$ & \multicolumn{2}{c}{ TP $(\mathbf{m g} / \mathbf{g})$} \\
\cline { 2 - 5 } & Sông Hậu & Kênh cấp & Sông Hậu & Kênh cấp \\
\hline T3 & $0,8 \pm 0,3^{\mathrm{a}}$ & $1,3 \pm 0,4^{\mathrm{a}}$ & $2,2 \pm 0,4^{\mathrm{a}}$ & $2,5 \pm 0,2^{\mathrm{a}}$ \\
T6 & $0,9 \pm 0,4^{\mathrm{a}}$ & $1,2 \pm 0,6^{\mathrm{a}}$ & $2,2 \pm 0,3^{\mathrm{a}}$ & $2,9 \pm 0,3^{\mathrm{b}}$ \\
T9 & $0,9 \pm 0,4^{\mathrm{a}}$ & $1,3 \pm 0,8^{\mathrm{a}}$ & $1,2 \pm 0,1^{\mathrm{a}}$ & $2,4 \pm 0,6^{\mathrm{b}}$ \\
T12 & $0,6 \pm 0,4^{\mathrm{a}}$ & $1,1 \pm 0,2^{\mathrm{a}}$ & $2,0 \pm 0,5^{\mathrm{a}}$ & $2,0 \pm 0,9^{\mathrm{a}}$ \\
\hline
\end{tabular}

* Các giá trị trung bình độ lệch chuẩn trong cùng một dòng có ký tụ giống nhau thì khác biệt không có ý nghĩa thống kê $(p>0,05)$

Bùn đáy tại các điểm thu chủ yếu là phù sa, keo khoáng tích tụ, đây là đặc điểm quan trọng của các con sông, kênh rạch vùng Đồng bằng sông Cửu Long. Tuy nhiên, do có sự tác động của nguồn nước ao nuôi cá tra thâm canh trong khu vực đã làm cho việc tích lũy dinh dưỡng dưới nền đáy bùn của thủy vực tự nhiên đã diễn ra nhiều hơn. Nông nghiệp là nguyên nhân chính gây ô nhiễm nguồn nước mặt trong các kênh nội đồng cùng với các hoạt động sinh hoạt hàng ngày và hoạt động công nghiệp. Điều này ảnh hưởng đến chất lượng nước mặt của sông Hậu do trao đổi nước với các kênh dẫn, liên thông (Nguyen Thanh Giao, 2019). Hàm lượng TN trong bùn đáy ao nuôi cá tra thâm canh được ghi nhận cao gấp 5-6 lần so với bùn đáy sông Cửu Long. Hàm lượng $\mathrm{TN}$ và $\mathrm{TP}$ bị ảnh hưởng bởi quá trình thay nước của ao nuôi cũng như thành phần vi sinh vật hiện diện trong bùn đáy (Trương Quốc Phú và ctv., 2012). Theo Hội Khoa học đất (2000), đất phù sa hệ thống sông Cửu Long có tỉ lệ TP là $0,05-0,1 \%$, thấp hơn nhiều so với hàm lượng $\mathrm{TN}$ và $\mathrm{TP}$ trong bùn đáy ao. Kết quả phân tích thành phần dinh dưỡng bùn đáy ao nuôi cá tra có $2,04 \mathrm{mg} / \mathrm{g}$ giá trị $\mathrm{TN}$ và 0,96 mg/g giá trị TP (Võ Nam Sơn và ctv., 2015). Hàm lượng $\mathrm{TN}$ và $\mathrm{TP}$ trong bùn đáy ao trước khi thả lần lượt là 1,97 và $0,39 \mathrm{mg} / \mathrm{g}$; tăng lên khi thu hoạch là 4,98 và $2,19 \mathrm{mg} / \mathrm{g}$ bùn khô (Lê Bảo Ngọc, 2004). Như vậy, việc nuôi cá tra đã làm cho sự tích tụ hàm 
lượng $\mathrm{TN}$ và $\mathrm{TP}$ trong bùn đáy cao hơn theo thời gian vụ nuôi. Việc trao đổi nguồn nước trong khu vực ao nuôi cá tra thâm canh đã làm cho hàm lượng $\mathrm{TN}$ và $\mathrm{TP}$ trong bùn ở thuỷ vực tự nhiên có xu hướng tăng cao, đặc biệt là các điểm thu thuộc nhóm kênh cấp chịu sự ảnh hưởng nhiều hơn so với thủy vực sông Hậu. Điều này cho thấy bùn đáy đã có sự tích lũy các hàm lượng dinh dưỡng trong nước từ các hoạt động xả thải sinh hoạt, nông nghiệp, đặc biệt là nguồn nước trao đổi từ khu vực nuôi thủy sản của vùng. Vì vậy, cần chú ý đến hàm lượng dinh dưỡng trong bùn đáy khi có nhu cầu sử dụng.

\subsection{Chlorophyll- $a$ và sự tương quan với các hàm lượng dinh dưỡng}

Kết quả cho thấy chlorophyll- $a$ có giá trị ở thủy vực kênh cấp cao hơn so với thủy vực sông Hậu qua 4 lần thu mẫu. Hàm lượng chlorophyll- $a$ dao động từ 7,0-63,3 $\mu \mathrm{g} / \mathrm{L}$ ở các điểm thu mẫu. Tại điểm thu kênh cấp, chlorophyll- $a$ có giá trị trung bình là $39,6 \pm 17,3 \mu \mathrm{g} / \mathrm{L}$ và có giá trị trung bình là $21,6 \pm 5,3$ $\mu \mathrm{g} / \mathrm{L}$ ở thủy vực sông Hậu qua các đợt thu. Điều này cho thấy hàm lượng dinh dưỡng trong nguồn nước tự nhiên ở khu vực nuôi cá tra trong nội đồng có xu hướng tích lũy cao hơn so với khu vực tự nhiên ngoài sông Hậu. Vì hàm lượng chlorophyll- $a$ được dùng như một chỉ số về mức độ phong phú của thực vật phù du. Theo Boyd \& Tucker (1998), hàm lượng chlorophyll- $a$ trong nước tăng, mật độ thực vật phù du tăng. Chúng có giá trị tî̉ lệ thuận với nhau. Ao nuôi thủy sản tốt thường có hàm lượng chlorophyll$a$ khoảng 50-200 $\mu \mathrm{g} / \mathrm{L}$. Đối với TCVN 6662:2000, khi xác định hàm lượng này trong nước có thể áp dụng tính toán cho lượng thực vật phù du trong nước mặt tự nhiên và để kiểm tra chu kỳ hay sự tăng trưởng của chúng (Bộ Khoa học, Công nghệ và Môi Trường, 2000). Kết quả cũng ghi nhận hàm lượng chlorophyll- $a$ có xu hướng giảm thấp vào mùa mưa $(\mathrm{T} 6, \mathrm{~T} 9)$ và tăng cao vào mùa khô $(\mathrm{T} 12, \mathrm{~T} 3)$. Điều này cũng thể hiện rằng hàm lượng dinh dưỡng trong nước tại các điểm thu có xu hướng tương tự, thấp vào mùa mưa và tăng cao vào mùa khô. Tuy nhiên, hàm lượng chlorophyll- $a$ tại các điểm thu vẫn còn ở mức thấp, ít ảnh hưởng đến sự ô nhiễm của thủy vực.

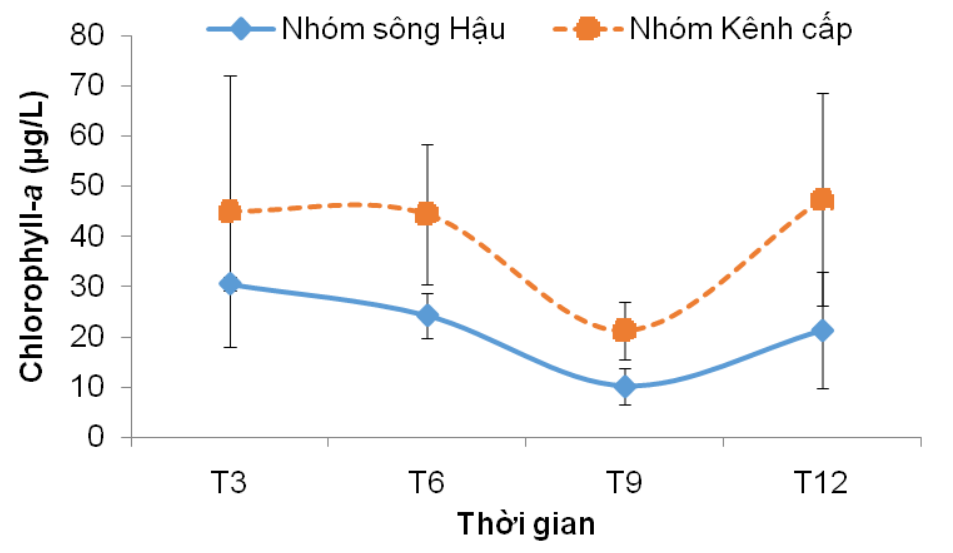

Hình 1. Biến động chlorophyll-a qua thời gian thu mẫu

Năng suất sinh học sơ cấp thủy vực thì được tính trên số lượng vật chất hữu cơ cố định được bởi quá trình quang hợp. Trong thủy vực, thực vật phù du thường là sinh vật sản xuất vật chất hữu cơ lớn nhất. Chính vì vậy, hàm lượng chlorophyll- $a$ có thể biểu thị cho việc sử dụng các nguồn dinh dưỡng trong nước để tăng năng suất sinh học sơ cấp thông qua chỉ số hàm lượng chlorophyll- $a$ có trong thực vật phù du trong thủy vực. Khi các hàm lượng dinh dưỡng trong nước tăng sẽ tạo điều kiện cho thực vật phù du phát triển. Khi thực vật phù du phát triển quá mức thì thủy vực đó được xem là ô nhiễm dinh dưỡng. Kết quả xử lý tương quan Pearson cho thấy hàm lượng chlorophyll- $a$ có sự tương quan thuận ở mức khá chặt và trung bình với các hàm lượng dinh dưỡng trong nước tại các thủy vực.

Đặc biệt, sự tương quan có ý nghĩa với các hàm lượng TSS, TAN, nitrate, $\mathrm{TN}$ và $\mathrm{TP}$ nước trong thủy vực $(\mathrm{p}<0,05)$. Kết quả cho thấy hàm lượng chlorophyll- $a$ vào $\mathrm{T} 3$ có sự tương quan thuận chặt chẽ với các hàm lượng dinh dưỡng trong nước, đặc biệt là có sự tương quan rất chặt với TSS và TN bùn, các yếu tố dinh dưỡng còn lại ở mức khá chặt chẽ và mức trung bình. Vào $\mathrm{T} 6$, chlorophyll- $a$ có sự tương quan ở mức rất chặt chẽ và khác biệt có ý nghĩa thống kê với TAN $(\mathrm{p}<0,01)$ và $\mathrm{TN}$ nước $(\mathrm{p}<0,05)$. Kết quả thống kê cũng cho thấy vào $\mathrm{T} 12$, sự tương quan cũng ở mức trung bình và khá chặt chẽ ở chlorophyll- $a$ và các yếu tố dinh dưỡng trong nước. 
Riêng vào $\mathrm{T} 3$, các yếu tố dinh dưỡng ở mức thấp nên sự tương quan chủ yếu là tương quan nghịch. Nhìn chung, kết quả xử lý tương quan cũng đã cho thấy được sự biến thiên của các hàm lượng dinh dưỡng trong thủy vực qua các đợt thu mẫu. Hàm lượng dinh dưỡng trong nước cao vào $\mathrm{T} 3, \mathrm{~T} 6$ và $\mathrm{T} 12$; có giá trị thấp vào $\mathrm{T} 9$ của thời gian thu mẫu.

Bảng 8. Tương quan chlorophyll- $a$ và các yếu tố dinh dưỡng ở 2 nhóm thủy vực

Sông Hậu

\begin{tabular}{|c|c|c|c|c|c|c|c|c|c|}
\hline $\begin{array}{l}\text { Các yếu tố } \\
\text { dinh dưỡng }\end{array}$ & TSS & TAN & Nitrate & Phosphate & TN bùn & TN Nước & TP bùn & TP nước & Chlorophyll- $a$ \\
\hline TSS & 1 & -.154 & -.006 & .159 & -.346 & -.167 & $-.604^{*}$ & .099 & .181 \\
\hline TAN & -.154 & 1 & $.579^{*}$ & .003 & $.810^{* *}$ & -.014 & .280 & .113 & .335 \\
\hline Nitrate & -.006 & $.579^{*}$ & 1 & -.022 & .465 & -.487 & -.039 & $.651^{*}$ & $.745^{* *}$ \\
\hline Phosphate & .159 & .003 & -.022 & 1 & -.215 & -.022 & -.065 & .180 & -.232 \\
\hline TN bùn & -.346 & $.810^{* *}$ & .465 & -.215 & 1 & -.183 & .201 & -.081 & .082 \\
\hline TN Nước & -.167 & -.014 & -.487 & -.022 & -.183 & 1 & -.015 & -.257 & -.255 \\
\hline TP bùn & $-.604^{*}$ & .280 & -.039 & -.065 & .201 & -.015 & 1 & -.166 & -.191 \\
\hline TP nước & .099 & .113 & $.651^{*}$ & .180 & -.081 & -.257 & -.166 & 1 & $.791^{* *}$ \\
\hline Chlorophyll- $a$ & .181 & .335 & $.745^{* *}$ & -.232 & .082 & -.255 & -.191 & $.791^{* *}$ & 1 \\
\hline \multicolumn{10}{|c|}{ Kênh cấp } \\
\hline TSS & 1 & .115 & .220 & .398 & .180 & .492 & .012 & -.538 & $.620^{*}$ \\
\hline TAN & .115 & 1 & .050 & .447 & $.844^{* *}$ & .430 & -.070 & -.161 & $.693^{*}$ \\
\hline Nitrate & .220 & .050 & 1 & -.068 & .144 & .021 & -.247 & .161 & .033 \\
\hline Phosphate & .398 & .447 & -.068 & 1 & .481 & .466 & -.079 & $-.607^{*}$ & .326 \\
\hline TN bùn & .180 & $.844^{* *}$ & .144 & .481 & 1 & .572 & .026 & .104 & .499 \\
\hline TN Nước & .492 & .430 & .021 & .466 & .572 & 1 & .213 & -.282 & .340 \\
\hline TP bùn & .012 & -.070 & -.247 & -.079 & .026 & .213 & 1 & .052 & .044 \\
\hline TP nước & -.538 & -.161 & .161 & $-.607^{*}$ & .104 & -.282 & .052 & 1 & -.473 \\
\hline Chlorophyll- $a$ & $.620^{*}$ & $.693^{*}$ & .033 & .326 & .499 & .340 & .044 & -.473 & 1 \\
\hline
\end{tabular}

* Tuong quan có ý nghĩa ở múc 0,05

** Tương quan có ý nghĩa ở múc 0,01

Đối với nhóm thủy vực kênh cấp nội đồng, kết quả cho thấy sự tương quan chặt chẽ diễn ra nhiều hơn ở thủy vực sông Hậu. Giá trị đạt ở mức trung bình đến khá chặt chẽ, riêng yếu tố TSS và TAN, sự tương quan có ý nghĩa thống kê $(p<0,05)$. Nhóm thủy vực sông Hậu cũng có các giá trị tương quan nhưng ở mức thấp, chỉ có yếu tố dinh dưỡng là nitrate và TP nước có sự tương quan khá chặt chẽ và có ý nghĩa thống kê $(\mathrm{p}<0,01)$. Nhìn chung, khi so sánh tương quan ở hai nhóm thủy vực giữa hàm lượng chlorophyll- $a$ và các yếu tố dinh dưỡng trong nước, thủy vực kênh cấp nội đồng có mức độ cao hơn và chặt chẽ hơn so với nhóm thủy vực sông Hậu. Như vậy, hàm lượng dinh dưỡng có giá trị tương quan và chặt chẽ với hàm lượng chlorophyll- $a$ trong nước tại các thủy vực. Có thể nói rằng khi hàm lượng dinh dưỡng trong nước cao đã góp phần làm tăng trưởng thực vật phù dù trong nước, làm cho hàm lượng chlorophyll- $a$ tăng theo. Qua đó cho thấy mức độ dinh dưỡng của các điểm thu tại thủy vực kênh cấp nội đồng có giá trị cao hơn so với các điểm thu tại thủy vực sông Hậu.

\section{KẾT LUẠN}

Hàm lượng dinh dưỡng tại các điểm thu ở kênh cấp nội đồng có giá trị cao hơn so với các điểm thu ở sông Hậu, đặc biệt là phosphate, TN và TP trong nước. Vào tháng 6 và tháng 9 , hàm lượng dinh dưỡng trong nước có xu hướng thấp hơn so với tháng 3 và tháng 12 tại các điểm thu mẫu.

Các kênh cấp nội đồng bị ảnh hưởng mạnh mẽ do sự tích tụ, lắng đọng, dòng chảy kém hơn so với thủy vực sông lớn, tuy nhiên vẫn còn ở mức thấp, nguồn nước vẫn phù hợp, đạt các yêu cầu trong phục vụ nuôi cá tra thâm canh của vùng.

Chất lượng nguồn nước đảm bảo tốt hơn vào tháng 6 và tháng 9 trong năm do hàm lượng dinh dưỡng trong nước thấp, có thể nuôi cá tra tập trung vào các tháng này để đảm bảo sức khỏe cá nuôi.

Cần có các biện pháp theo dõi, xử lý chặt chẽ các hàm lượng dinh dưỡng trong nước khi cần sử dụng nguồn nước, đặc biệt là hàm lượng $\mathrm{TAN}$, phosphate tùy từng mục đích sử dụng khác nhau. 


\section{LỜI CẢM TẠ}

Đề tài này được tài trợ bởi Dự án Nâng cấp Trường Đại học Cần Thơ VN14-P6 bằng nguồn vốn vay ODA từ Chính phủ Nhật Bản.

\section{TÀI LIỆU THAM KHẢO}

Anh, P.K. \& Giao, N.T. (2018). Groundwater Quality and Human Health Risk Assessment Related to Groundwater Consumption in an Giang Province. J Heavy Met Toxicity. Dis Vol.3 No.2:4. doi: 10.21767/2473-6457.10023.

APHA. (2012). Standard Methods for Examination of Water and Wastewater (22 ${ }^{\text {nd }}$ ed.). American Public Health Association, Washington DC.

APHA, AWWA, WEF. (1995). Standard methods for the examination of water and wastewater (19 ${ }^{\text {th }}$ ed.). American Public Health Association, Washington DC.

Bộ Khoa học, Công nghệ và Môi Trường. (2000). TCVN 6662:2000, ISO10260:1992. Chất lương nuoóc - Đo thông số sinh hóa-Phuơng pháp đo phổ xác định nồng độ Chlorophyll-a.

Bộ Tài nguyên và Môi trường. (2011). QCVN 38:2011/BTNMT. Quy chuẩn kỹ thuật quốc gia về chất luợng nước mặt bảo vệ đời sống thủy sinh.

Bộ Tài nguyên và Môi trường. (2014). QCVN 0220:2014/BNNPTNT. Quy chuẩn kỹ thuật quốc gia về cơ sở nuôi cá Tra (Pangasianodon hypophthalmus Sauvage, 1878) trong ao.

Bộ Tài nguyên và Môi trường. (2015). QCVN 08MT: 2015/BTNMT. Quy chuẩn kỹ thuật quốc gia về chất luợng nước mặt.

Bộ Thủy sản. (2014). Tiêu chuẩn ngành số 28 TCN213:2004. Quy trình kỹ thuật nuôi thâm canh cá Tra.

Boyd, C.E. (1998). Water quality for pond aquaculture. Research and development series. No.43.

Boyd, C.E. \& Tucker, C.S. (1998). Pond Aquaculture Water Quality Management. Boston, Kluwer Academic, London, ISBN-10: 0412071819.

Boyd, C.E. \& Green, B.W. (2002). Water quality monitoring in shrimp farming areas: an example from Honduras, Shrimp Farming and the Environment. Report prepared under the World Bank, NACA, WWF and FAO Consortium Program on Shrimp Farming and the Environment, Auburn, USA.

Cao Văn Thích. (2008). Biến đổi chất luợng nước và tích lũy vật chất dinh duõong trong ao nuôi cá tra thâm canh (Luận văn tốt nghiệp Thạc sĩ Nuôi trồng thủy sản). Trường Đại học Cần Thơ.

Chi cục Thủy sản Cần Thơ. (2020). Báo cáo Tổng kết quan trắc môi trương phục vụ nuôi trồng thủy sản trên địa bàn thành phố Cần Tho giai đoạn 2016-2020. Chi cục Thủy sản Cần Thơ.

Hội Khoa học Đất Việt Nam. (2000). Đất Việt Nam. Nhà xuất bản Nông nghiệp.

Le Anh Tuan, Huynh Vuong Thu Minh, Dinh Diep Anh Tuan \& Nguyen Thi Phuong Thao. (2015). Baseline Study for Community Based Water Management Project; Mekong Water Governance Program Vietnam. Hanoi, Vietnam. https://www.researchgate.net/publication/281462603

Lê Bảo Ngọc. (2004). Đánh giá chất luoọng môi truòng ao nuôi cá tra thâm canh ở Tân Lộc, Thốt Nốt, Cần Tho (Luận văn Cao học ngành Khoa học môi trường). Trường Đại học Cần Thơ.

Lê Hoàng Nam, Nguyễn Văn Bé \& Nguyễn Võ Châu Ngân. (2017). Khảo sát chất lượng nước ao nuôi cá tra công nghiệp phục vụ quản lý chất lượng ao nuôi. Tạp chí Khoa học Đại học Thủ Dầu Một, 4(35), 46-58.

Ly, N.H.T. \& Giao, N.T. (2018). Surface water quality in canals in An Giang Province, Viet Nam, from 2009 to 2016. Journal of Vietnamese Environment, 10(2), 113-119. DOI: 10.13141/jve.vol10.no2.pp113-119

Minh, H.V.T., Kurasaki, M., Ty, V.T., Tran, D.Q., Le, K.N., Avtar, R., Rahman, M. \& Osaki, M. (2019). Effects of Multi-Dike Protection Systems on Surface Water Quality in the Vietnamese Mekong Delta. Water, 11(1010), 1-23.

Nguyễn Hữu Lộc. (2009). Sụ biến đổi chất lương trong hệ thống nuôi cá Tra (Pangasianodon hypopthalmus) thâm canh ở các quy mô khác nhau (Luận văn tốt nghiệp Cao học Ngành Nuôi trồng thủy sản). Trường Đại học Cần Thơ.

Nguyễn Nhứt, Lê Ngọc Hạnh \& Nguyễn Văn Hảo. (2013). Ước tính phát thải của ao nuôi cá tra (Pangasianodon hypophthalmus) thâm canh ở đồng bằng sông Cửu Long. Tạp Chí Nghề Cá Sông Cưu Long, 1, 20-29.

Nguyễn Phú Hòa. (2012). Chất luợng môi trường nuớc trong nuôi trồng thủy sản. Nhà xuất bản Nông Nghiệp.

Nguyen Thanh Giao. (2019). Surface water quality in the canals influenced by agricultural activities in An Giang province. Journal of Science on Natural Resources and Environment, 21, 73-82.

Nguyen Thanh Giao. (2020). Evaluating surface water quality and testing frequency in Tien and Hau rivers, An Giang province, using 10-year monitoring data. Journal of Tra Vinh university, 37, 78-88.

DOI:10.35382/18594816.1.37.2020.379

Huỳnh Thị Tú, Trần Văn Nhì, Trần Văn Bùi, Trần Thị Thanh Hiền \& Nguyễn Thanh Phương. (2006). Tình hình nuôi và sử dụng thức ăn cho cá 
tra nuôi ao và nuôi bè ở An Giang. Tap chí Khoa hoc Truòng Đại học Cần Tho', 1, 152-157.

Nguyễn Thị Kim Liên, Lâm Quang Huy, Dương Thị Hoàng Oanh, Trương Quốc Phú \& Vũ Ngọc Út. (2016). Chất lượng nước trên sông chính và sông nhánh thuộc tuyến sông Hậu. Tạp chí Khoa hoc Trưòng Đại học Cần Tho, Phần A: Khoa hoc Tụ nhiên, Công nghệ và Môi truò̀ng, 43, 68-79.

Campbell, I. C. (2009). The Mekong: Biophysical environment of an international river basin. In Ongley, E.D. (Eds), Water Quality of the Lower Mekong River. (297-320). ScienceDirect. https://www.sciencedirect.com/book/978012374 0267/the-mekong

Patz, J. A., Diarmid, C.L., Tracey, H. \& Jonathan, A. F. (2005). Impact of regional climate change on human health. Nature, 438, 310-317.

Phạm Lê Mỹ Duyên, Phạm Văn Toàn, Văn Phạm Đăng Trí \& Nguyễn Hữu Chiếm. (2015). Chất lượng nước mặt và khả năng tự làm sạch của hệ thống kênh trong vùng đê bao khép kín ở thị trấn Mỹ Luông, huyện Chợ Mới, tỉnh An Giang. Tạp chí Khoa học Trường Đại học Cần Tho, 39, 97-104.

Phạm Quốc Nguyên \& Lê Hồng Y. (2011). Nghiên cứu động thái đạm vô cơ trong ao và độc tính của tổng đạm amon lên cá tra (Pangasianodon hypoththalmus) cỡ giống. Đề tài Khoa hoc Công nghệ cấp co sở, Truờng Đại hoc Cần Tho; Cần Tho:

Phạm Quốc Nguyên, Nguyễn Thị Ngọc Yến, Trương Quốc Phú, Nguyễn Văn Công. (2015). Ảnh hưởng của tổng đạm amôn lên sinh trưởng cá tra (Pangasianodon hypophthalmus). Tap chí Khoa hoc Đại học Su phạm Thành phố Hồ Chí Minh, 5(70), 168-180.

Sở Nông nghiệp và Phát triển nông thôn tỉnh An Giang. (2021, tháng 3, 15). Sản lượng cá tra tăng $n h e$. https://baoangiang.com.vn/san-luong-ca-tratang-nhe-a298640.html

Tăng Đức Thắng \& Tô Quang Toản. (2016). Tác động của biến đổi khí hậu, phát triển thượng nguồn, phát triển nội tại tới đồng bằng sông Cửu Long, thách thức và giải pháp ứng phó. Tuyển tập Hội nghị Khoa học thường niên.

Thái Thị Nguyên. (2013). Biến động chất luợng nuớc trên sông Hậu (Luận văn tốt nghiệp Cao học ngành Nuôi trồng thủy sản). Trường Đại học Cần Thơ.

Thu, T.A., Tinh, T.K. \& Minh, V.Q. (2011). Investigating sources of arsenic contamination in groundwater in An Phu district. Can Tho University Journal of Science, 17a, 118-123.

Tô Quang Toản. (2016). Báo cáo tổng hợp kết quả KH\&CN: Nghiên cứu đánh giá tác động của các bậc thang thủy điện trên dòng chính hạ lưu sông Mê Kông đến dòng chảy, môi trường, kinh tế xã hội vùng đồng bằng sông Cửu Long và đề xuất giải pháp giảm thiểu bất lợi. Đề tài cấp nhà nước - KC08.13/11-15.

Trần Thị Thanh Thủy \& Đặng Thị Thúy Hạt. (2017). Nghiên cứu ảnh hưởng của một số ion đến việc xác định hàm lượng Photphate trong nước tự nhiên. Tạp chí Quản lý Tài nguyên rù̀ng và Môi Truò̀ng, 20, 101-108.

Trần Trung Giang, Aina Ayotunde Oluwadamilare, Âu Văn Hóa, Huỳnh Trường Giang, Trương Quốc Phú, Minoru Wada \& Vũ Ngọc Út. (2020). Đánh giá chất lượng nước trong khu vực nuôi tôm tỉnh Sóc Trăng. Tạp chi Khoa hoc Truò̀ng Đại hoc Cần Tho, 56(Số chuyên đề: Thủy sản)(1), 112-120. https://doi:10.22144/ctu.jsi.2020.013

Trung tâm Quan trắc và Kỹ thuật Tài nguyên - Môi trường An Giang. (2018). Báo cáo kết quả quan trắc môi truờng tỉnh An Giang - Đợt tháng 6 năm 2018. Trung tâm Quan trắc và Kỹ thuật Tài nguyên - Môi trường An Giang.

Trương Quốc Phú, Trần Kim Tính \& Huỳnh Trường Giang. (2012). Khả năng sử dụng bùn thải ao nuôi cá tra (Pangasianodon hypophthalmus) thâm canh cho canh tác lúa. Tạp chí Khoa học Trưòng Đại học Cần Tho, 24a, 135-143.

Võ Nam Sơn, Nguyễn Dương Anh, Phan Thanh Lâm, Lý Văn Khánh, Trần Ngọc Hải \& Nguyễn Thanh Phương. (2015). Khảo sát thành phần dinh dưỡng và lợi ích sử dụng bùn đáy ao nuôi cá tra trong nông nghiệp tại đồng bằng sông Cửu Long. Tạp chí Khoa hoc Truờng Đại hoc Cần Tho: Phần B: Nông nghiệp, Thủy sản và Công nghệ Sinh hoc, 38, 116-123.

Vũ Ngọc Út, Nguyễn Bạch Loan, Huỳnh Trường Giang, Dương Thị Hoàng Oanh, Nguyễn Thị Kim Liên, Nguyễn Bá Quốc, Nguyễn Văn Ngoan, Âu Văn Hóa \& Phan Thị Cẩm Tú. (2013). Nghiên cứu biện pháp hạn chế sự phát triển của vẹm vàng Limnoperna fortunei sống bám trên ốc gạo (Cipangopaludina lecithoides) trên địa bàn huyện Chợ Lách, Bến Tre. Báo cáo tổng kết đề tài cấp Bộ. 